УДК 517.9

\title{
Iron Sulfide Nanoparticles: \\ Preparation, Structure, Magnetic Properties
}

Ruslan D. Ivantsov*

Irina S. Edelman ${ }^{\dagger}$

Andrey A. Dubrovsky ${ }^{\ddagger}$

Kirensky Institute of Physics, Federal Research Center KSC SB RAS

Akademgorodok, 50/38, Krasnoyarsk, 660036

Russia

Sergey M. Zharkov ${ }^{\S}$

Dmitry P. Velikanov

Kirensky Institute of Physics, Federal Research Center KSC SB RAS

Akademgorodok, 50/38, Krasnoyarsk, 660036

Siberian Federal University

Svobodny, 79, Krasnoyarsk, 660041

Russia

Chun-Rong Lin $\|$

Yaw-Teng Tseng

Department of Applied Physics, National Pingtung University

Pingtung City, Pingtung County, 90003

Taiwan

Kun-Yauh Shih

Department of Applied Chemistry, National Pingtung University

Pingtung City, Pingtung County, 90003

Taiwan

Received 18.10.2016, received in revised form 19.10.2016, accepted 03.02.2017

The series of iron sulfide nanoparticles (NPs) were synthesized with the polyol mediated process which exploits high-boiling polyalcohol solvents at different boiling temperatures $\left(T_{B}\right)$ what determined the NPs phase state from $\mathrm{Fe}_{3} \mathrm{~S}_{4}$ to $\mathrm{FeS}$. The XRD and HRTEM revealed the content of the $\mathrm{Fe}_{3} \mathrm{~S}_{4}$ cubic phase to reduce linearly with the $T_{B}$ increase, and at $T_{B}=320^{\circ} \mathrm{C}$ the $\mathrm{FeS}$ phase became predominant. Non monotonous coercivity dependence on the NPs phase state is revealed and interpreted.

Keywords: Fe sulfides, $\mathrm{Fe}_{x} \mathrm{~S}_{y}$, nanoparticles, magnetic properties.

DOI: $10.17516 / 1997-1397-2017-10-2-244-247$.

Iron sulphide nanoparticles (NPs) attract great attention owing, in particular, to wide range of their applications (e.g., [1-4]). Iron sulfide compounds $\mathrm{Fe}_{x} \mathrm{~S}_{y}$ demonstrate a wide range of

*ird@iph.krasn.ru

$\dagger$ ise@iph.krasn.ru

†andre-do@yandex.ru

$\S_{\text {zharkov@iph.krasn.ru }}$

ฯadpona1@gmail.com

$\|_{\text {crlin@mail.nptu.edu.tw }}$

(c) Siberian Federal University. All rights reserved 
magnetic properties in dependence on the $\mathrm{x}: \mathrm{y}$ ratio. The most frequently studied among them are $\mathrm{FeS}, \mathrm{Fe}_{7} \mathrm{~S}_{8}, \mathrm{Fe}_{3} \mathrm{~S}_{4}$, and $\mathrm{FeS}_{2}$, called troilite, pyrrhotite, greigite and pyrite, respectively. Many authors have shown that the phase state and properties of iron sulfide NPs are exceptionally sensitive to the technological conditions what can be used to control these properties. The present paper is devoted to the role of the boiling temperature $\left(\mathrm{T}_{B}\right)$ on the phase composition and properties of $\mathrm{Fe}_{x} \mathrm{~S}_{y}$ (NPs) fabricated with polyol mediated process.

All reagents are of analytic purity and were used without further purification. In a typical synthesis, a mixture of iron nitrate $\left(\mathrm{Fe}\left(\mathrm{NO}_{3}\right)_{3} \cdot 9 \mathrm{H}_{2} \mathrm{O}\right)$, sulfur powder $(\mathrm{S})$, and octadecylamine (ODA) were added into a three-neck round-bottom flask equipped with a magnetic stirrer and an inlet of argon gas. The mixture was dewatered at $120{ }^{\circ} \mathrm{C}$ for $30 \mathrm{~min}$, and then heated to $200{ }^{\circ} \mathrm{C}$ with a rate of $10 \mathrm{~K} / \mathrm{min}$, maintained at this temperature for $30 \mathrm{~min}$, and, finely, heated to refluxing temperatures $\left(\mathrm{T}_{B}\right.$ between 240 and $320^{\circ} \mathrm{C}$ for $1 \mathrm{hr}$. The resulting black NPs powder was collected by a magnet and rinsed with $70{ }^{\circ} \mathrm{C}$ solvent of ethanol/hexane several times to remove ODA, and dried in a vacuum at $80{ }^{\circ} \mathrm{C}$ for $1 \mathrm{hr}$. Notations NPs 240, NPs 250, and so, will be used further in accordance with $\mathrm{T}_{B}$.

XRD patterns of NPs powdered samples are shown in Fig. 1. Almost all peaks of NPs 240 (Fig. 1 a) ) and 250 were indexed by cubic cell (Fd-3m) with parameters close to $\mathrm{Fe}_{3} \mathrm{~S}_{4}$, greigite [PDF4+ No 04-008-7806], while all peaks of NPs 320 were indexed by hexagonal cell (P63/mmc) with parameters which can be referred both to $\mathrm{Fe}_{7} \mathrm{~S}_{8}$, pyrrhotite [PDF4+ No04-011-1582], or to FeS, troilite. Coexistence of several phases was indicated for all other samples (Fig. 1 b) ). Note that, in principle, $\mathrm{Fe}_{7} \mathrm{~S}_{8}$ can exist both in hexagonal and monoclinic phases. At that, first of them is antiferromagnetic while the second one is ferromagnetic. HRTEM image of the NPs 240 has shown that most of the nanoparticles are irregular near-rectangular or hexagon plates with lateral dimensions of about $50 \mathrm{~nm}$. The SAED data describing the nanoparticles local structure were identical to the XRD data. Both SAED and XRD give no unambiguous answer about the higher temperature phase: whether it was $\mathrm{Fe}_{7} \mathrm{~S}_{8}$ or $\mathrm{FeS}$.
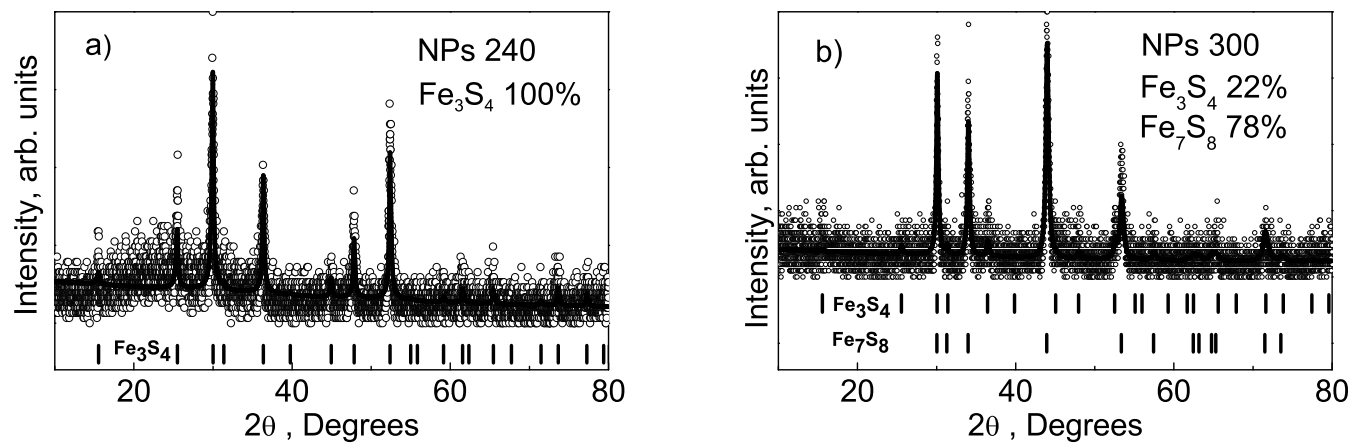

Fig. 1. The difference Rietveld plots of the samples NPs 240 (a) and NPs 300 (b)

Fig. 2 a) shows the magnetization curves of several samples with hysteresis loops indicating the typical ferromagnetic behavior. The magnetization curve characteristics of NPs 240 are in good agreement with that reported for $\mathrm{Fe}_{3} \mathrm{~S}_{4}$. Identity of hysteresis loops shape of NPs 240-280 and the gradual magnetization decrease from NPs 240 to NPs 280 allow statement that they consist of the ferromagnetic $\mathrm{Fe}_{3} \mathrm{~S}_{4}$ phase and the phase having no resulting magnetic 

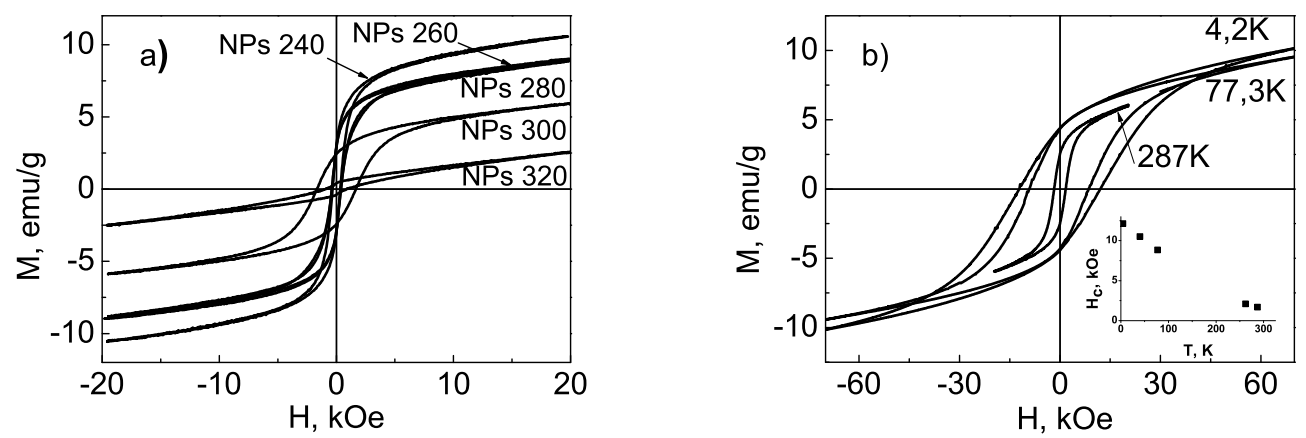

Fig. 2. a) Room temperature hysteresis loops of nanoparticles, NPs numbers are shown in the graph. b) Hysteresis loops of NPs 300 at different measurement temperatures. Inset: The sample NPs $300 \mathrm{H}_{c}$ temperature dependence

moment, that is, FeS or/and hexagonal $\mathrm{Fe}_{x} \mathrm{~S}_{y}$. For NPs 300, the hysteresis loop shape changes dramatically: room temperature coercivity, $\mathrm{H}_{c}$, becomes approximately one order of value larger comparing to other samples and it increases strongly with the temperature decrease (Fig. 2 b) ) while for other samples $\mathrm{H}_{c}$ is almost independent of temperature (Fig. 3). The NPs $300 \mathrm{H}_{c}$ temperature behavior (inset in Fig. $2 \mathrm{~b}$ ) ) recollects the $\mathrm{H}_{c}$ increase observed for the monoclinic $\mathrm{Fe}_{7} \mathrm{~S}_{8}$ NPs observed in Ref. [5]. At the same time, XRD detects the hexagonal phase prevalence in NPs 300. So, one can conclude that ferromagnetic state can be realized in the hexagonal $\mathrm{Fe}_{7} \mathrm{~S}_{8}$ NPs, possibly, because of small lattice distortions or strains. The assumption can be supported by the fact that after the additional heating of this sample at $200^{\circ} \mathrm{C}$ during $1 \mathrm{hr}$, peculiarities of the hysteresis loop disappears and it becomes similar to loop of NPs 240-280. For NPs boiled at higher temperatures, hysteresis loop changes again. Magnetization curve looks like the superposition of the wide hysteresis loop with very low $\mathrm{M}_{s}$ and paramagnetic contribution.

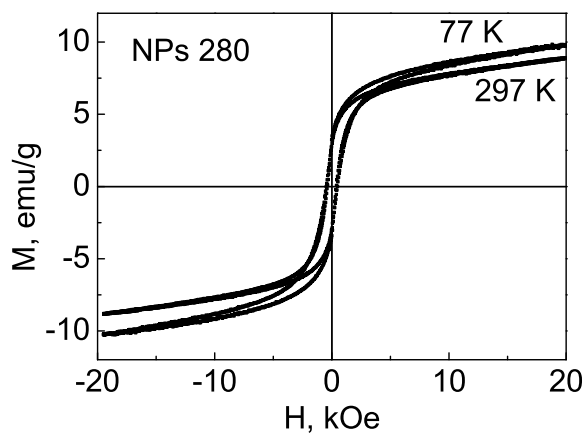

Fig. 3. Hysteresis loops of NPs 280 at temperatures 297 and $77 \mathrm{~K}$

Combining the results of magnetic measurements with the structural data, the next phase compositions of NPs ensembles under study could be proposed. NPs 240 contains the $\mathrm{Fe}_{3} \mathrm{~S}_{4}$ phase only. NPs 250, 260, 280 contain $\mathrm{Fe}_{3} \mathrm{~S}_{4}$ phase in the diminishing concentrations and $\mathrm{FeS}$ in the growing concentrations. NPs 300,310 contain $\mathrm{Fe}_{7} \mathrm{~S}_{8}$ phase, at that high coercivity ferromagnetic 
state is possible in the hexagonal $\mathrm{Fe}_{7} \mathrm{~S}_{8}$. NPs 320 contain some nonmagnetic phase and $\mathrm{Fe}_{3} \mathrm{O}_{4}$ phase in superparamagnetic state at higher temperatures and in the frozen ferrimagnetic state at lower temperatures. Phase composition and magnetic properties of iron sulphide NPs synthesized with polyol mediated process can be governed by the boiling temperature.

The work was supported by the President of Russia Grant NSh-7559.2016.2.

\section{References}

[1] A.B.Seabra, P.Haddad, N.Duran, Biogenic synthesis of nanostructured iron compounds: applications and perspectives, IET Nanobio-Technology, 7(2013), no. 3, 90-99.

[2] K.Zhang, T.Zhang, J.Liang, Y.Zhu, N.Lina, Y.Qian, A potential pyrrhotite $\left(\mathrm{Fe}_{7} \mathrm{~S}_{8}\right)$ anode material for lithium storage, $R S C A d v$, 5(2015), 14828-14831.

[3] X.Li, H.Xu, Z.S.Chen, G.Chen, Biosynthesis of nanoparticles by microorganisms and their applications, J. Nanomater, 5(2011), Art. ID 270974.

[4] X.Wang, W.Cai, G.Wang, Z.Wua, H.Zhao, One-step fabrication of high performance micro/nanostructured $\mathrm{Fe}_{3} \mathrm{~S}_{4}-\mathrm{C}$ magnetic adsorbent with easy recovery and regeneration properties, Cryst. Eng. Comm., 15(2013), 2956-2965.

[5] P.Rochette, G.Fillion, J.L.Mattei, M.J.Dekkers, Magnetic transition at 30- $34 \mathrm{~K}$ in $\mathrm{Fe}_{7} \mathrm{~S}_{8}$ : Insight into a widespread occurrence of pyrrhotite in rocks. Earth Planet, Sci. Lett., 98(1998), no. 3-4, 319-328.

\section{Наночастицы сульфида железа: синтез, структура, магнитные свойства}

Руслан Д. Иванцов, Ирина С. Эдельман, Андрей А. Дубровский Институт физики им. Л. В. Киренского, КНЦ СО РАН Академгородок, 50/38, Красноярск, 660036

Россия

Сергей М. Жарков, Дмитрий П. Великанов

Сибирский федеральный университет Свободный, 79, Красноярск, 660041

Россия

Чун-Рон Лин, Йау-Тенг Чжень, Кун-Йау Ши, Департамент прикладной физики, Национальный университет Пинтунга Пинтунг, район Пинтунга, 90003

Тайвань

Серия наночастич, (NPs) сульфидов железа синтезирована с помощью полиольного метода, $\theta$ котором используются высокотемпературные растворы полиспиртов при различных темпераmyрах (T $\left.T_{B}\right)$, что определяет фазовый состав $N P s$ om $\mathrm{Fe}_{3} S_{4}$ до FeS. XRD и HRTEM показали, что содержание кубической фазы $\mathrm{Fe}_{3} \mathrm{~S}_{4}$ в $\mathrm{NPs}$ линейно уменъшается при увеличении $T_{B}$ и при $T_{B}=320^{\circ} \mathrm{C}$ гексагональная фаза $\mathrm{FeS}$ становится преобладающей. Обнаружена и обблснена немонотонная зависимость коэриитивной силы NPs от их фазового состава.

Ключевые слова: сульфиды железа, $F e_{x} S_{y}$, наночастицы, магнитные свойства. 